本邦に抢けるアフリカ型 PPNG の検出

\author{
都立台東病院泌尿器科 \\ 岡 崎 武二 郎 \\ 都立衛生研究所 \\ 大橋誠一言広石上武 \\ 東京慈恵会医科大学泌尿器科 \\ 町田豊平 小野寺昭一 \\ (平成 1 年 6 月 20 日受付) \\ (平成 1 年 8 月 7 日受理)
}

Key words : PPNG, African type PPNG, Plasmid DNA

要旨

1988年に都立台東病院泌尿器科の男子淋菌性尿道炎患者から分離された PPNG 22 株について,プラス ミドDNA の測定を行った。

PPNG 22株のうち 3 株 (14\%) は3.3×ガダルトンのプラスミドを有し，しかも 3 株全部が同時に24.5 メガダルトンの耐性伝達プラスミドをも有する新アフリカ型 PPNGであった。また，22株のうち19株 (86\%) は4.4メガダルトンのプラスミドを有するアジア型であり，この19株のうち 5 株（26\%）は24.5 メガダルトンのプラスミドを有していた。

新アフリカ型 PPNG 3 症例の感染源は, 1 例はフィリピンであったが, 2 例は都内のソープランドで あり，新アフリカ型PPNG がすでに国内に定着していることが示唆された。

\section{I. 序 文}

Penicillinase producing Neiserria gonohrroeae (PPNG) には3.3メガダルトンのプラスミドを持 つアフリカ型と 4.4 メガダルトンのプラスミドを 持つアジア型があることが知られている11. 本邦 では，これまでアジア型PPNG は報告されてい る2) か)が，まだアフリカ型PPNGは報告されてい ない。われわれは，1988年に臨床分離された淋菌 のなかにアフリカ型 PPNG を検出したので報告 する.

\section{II. 材料と方法}

検索された菌株は，1988年に都立台東病院泌尿 器科の男子淋菌性尿道炎患者から分離 - 同定 - 保 存された淋菌で, PPNG 22株, 非 PPNG 79株, 合計101株である。これら101株を対象として, 寒

\footnotetext{
別刷請求先：（干111）台東区千東 $3-20-5$ 都立台東病院泌尿器科

岡崎武二郎
}

天ゲル電気泳動法によるプラスミド DNA の測定 を行なった。

電気泳動は, 寒天濃度 $1 \%$, 電圧 40 ボルト, 泳 動時間18時間で行なった. プラスミドDNAの分 子量測定には, 分子量の知られている検定株 (E. coli，V 517）を使用した。

淋菌の $\beta$-lactamase 活性測定は, Cephalosporin 87/132（Glaxo）を使用した変色基質法で行っ た。また，臨床分離淋菌に拈いて Benzylpenicllin (PCG), tetracyclin (TC) の最小発育阻止濃度 （MIC）を平板希橎法で測定した。

\section{III. 成 績}

1988年 1 月と 2 月に分離された淋菌13株のプラ スミドDNAの電気泳動パターンを Fig. 1 に示 した。

No. 1 から No. 6 までの株が PPNG, No. 7 か ら No. 13 までの株は非 PPNGでる。このうち, 
Fig. 1 Agarose gel electrophoresis of plasmid DNA from $N$. gonorrhoeae 13 strains

Md: megadalton, Ch. DNA : chromosome DNA
$2.6 \mathrm{md} \quad 3.3 \mathrm{mo}$
4. $4 \mathrm{~m}$
Ch. DNA 24.5 M

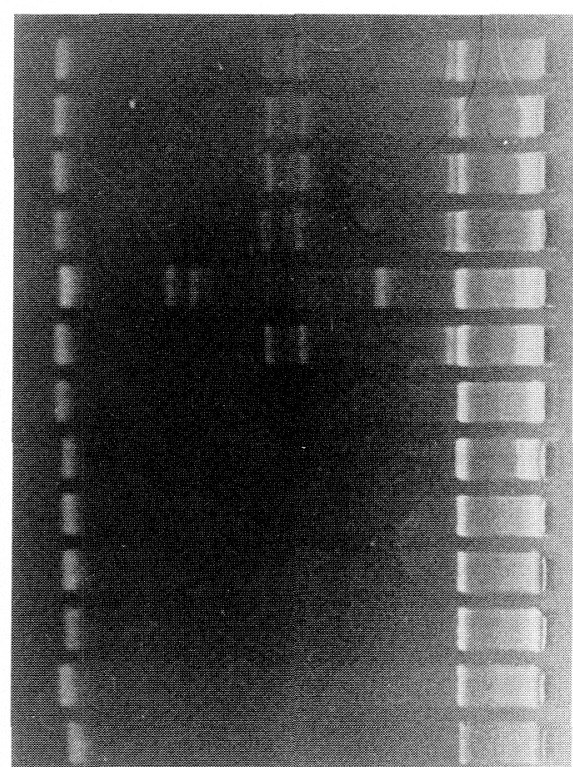

Table 1 Plasmid DNA pattarns of $N$. gonorr hoeae 101 strains (PPNG: 22 strains, NonPPNG : 79 strains)

\begin{tabular}{ccccc}
\hline \multirow{2}{*}{ PPNG } & \multicolumn{3}{c}{ Plasmid(megadalton) } & \multirow{2}{*}{$\begin{array}{c}\text { No. of } \\
\text { strains }\end{array}$} \\
\cline { 2 - 4 } & 3.3 & 4.4 & 24.5 & \\
\hline \multirow{2}{*}{ PP } & $(+)$ & $(-)$ & $(+)$ & 3 \\
& $(-)$ & $(+)$ & $(-)$ & 14 \\
& $(-)$ & $(+)$ & $(+)$ & 5 \\
\hline \multirow{2}{*}{ Non-PPNG } & $(-)$ & $(-)$ & $(-)$ & 43 \\
& $(-)$ & $(-)$ & $(+)$ & 36 \\
\hline
\end{tabular}

(46\%)であった。

1988年に分離されたPPNG 22株の全症例につ いての臨床所見和よびプラスミドDNAの電気泳 動成績を Table 2 に示した。

アフリカ型PPNGの感染源をみると，1例が フィリピン， 2 例は時期の異なる都内のソープラ ンドであった。

アフリカ型 PPNG 3 株の薬剂感受性を及る そ, $\mathrm{PCG}$ の $\mathrm{MIC}$ は $5 \mu \mathrm{g} / \mathrm{ml}$ と $100 \mu \mathrm{g} / \mathrm{ml}$ 以上で 高度耐性, TC $23.13 \mu \mathrm{g} / \mathrm{ml}$ と $6.25 \mu \mathrm{g} / \mathrm{ml}$ で耐性 であった。

\section{IV. 考 察}

PPNG (中，1976年にイギリス ${ }^{6)}$ アアメリカ7)で報 告されて以来，全世界で広く報告されている。本 邦では1979年小野田ら ${ }^{8)}$ の報告以後, 各地で報告 されるよらになり，最近では全国的に10２0\%の 頻度で PPNG が瞢延している5).

PPNGには4.4メガダルトンのプラスミドを持 つアジア型PPNGと3.3メガダルトンのプラス ミドを持つアフリカ型PPNGのあることが知ら れている1).アジア型 PPNGには24.5メガダルト ンの耐性伝達プラスミドを持つ株が認められてい たが，アフリカ型には24.5メガダルトン・プラス ミドを持つ株は, 従来認められていなかった。し

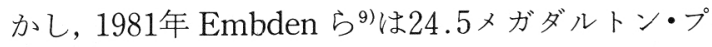
ラスミドを持つアフリカ型 PPNGを報告し，こ のよらな株は新アフリカ型 PPNGと呼ばれてい る.

本邦では，従来，アジア型 PPNGのみでアフリ 力型 PPNG 報告されていなかった。しかし，社 
Table 2 Clinical Data and Plasmid type of 22 PPNG Strains isolated in 1988 Metropolitan Taito Hospital

\begin{tabular}{|c|c|c|c|c|c|c|c|c|}
\hline \multirow{2}{*}{ Case } & \multirow{2}{*}{ Age } & \multirow{2}{*}{ Date } & \multirow{2}{*}{$\begin{array}{l}\text { Source of } \\
\text { Infection }\end{array}$} & \multicolumn{2}{|c|}{$\operatorname{MIC}(\mu \mathrm{g} / \mathrm{ml})$} & \multicolumn{3}{|c|}{ Plasmid(Md) } \\
\hline & & & & PCG & $\mathrm{TC}$ & 3.3 & 4.4 & 24.5 \\
\hline 1) $\mathrm{SO}$ & 46 & JAN & Soup Land & 25 & 3.13 & & $(+)$ & $(-)$ \\
\hline 2) $\mathrm{HK}$ & 38 & JAN & Indonesia & 6.25 & 6.25 & & $(+)$ & $(t)$ \\
\hline 3) $\mathrm{HK}$ & 29 & JAN & Hostess & $100<$ & 6.25 & & $(+)$ & $(+)$ \\
\hline 4) $\mathrm{R} \mathrm{S}$ & 48 & FER & Hostess & 25 & 12.5 & & $(+)$ & $(-)$ \\
\hline 5) $\mathrm{MH}$ & 39 & FER & Philippines & 50 & 6.25 & $(+)$ & & $(+)$ \\
\hline 6) $\mathrm{SO}$ & 47 & FER & Hostess & 50 & 3.13 & & $(+)$ & $(+)$ \\
\hline 7) $\mathrm{YF}$ & 39 & MAR & Taiwan & 100 & 6.25 & & $(+)$ & $(-)$ \\
\hline 8) $\mathrm{KK}$ & 22 & MAR & Korea & 25 & 0.8 & & $(+)$ & $(-)$ \\
\hline 9) $\mathrm{MT}$ & 24 & MAR & Call Girl & $100<$ & 12.5 & & $(+)$ & $(-)$ \\
\hline 10) $\mathrm{MN}$ & 30 & JUN & Soup Land & $100<$ & 6.25 & & $(+)$ & $(+)$ \\
\hline 11) $\mathrm{S} \mathrm{U}$ & 38 & JUN & Soup Land & $100<$ & 3.13 & $(+)$ & & $(+)$ \\
\hline 12) $\mathrm{YK}$ & 36 & JUN & Korea & $100<$ & 12.5 & & $(+)$ & $(-)$ \\
\hline 13) $\mathrm{HK}$ & 37 & JUN & Soup Land & $100<$ & 1.6 & & $(+)$ & $(t)$ \\
\hline 14) $\mathrm{HO}$ & 24 & JUL & Korea & $100<$ & 12.5 & & $(+)$ & $(-)$ \\
\hline 15) Y I & 28 & AUG & Thailand & N.T & N.T & & $(+)$ & $(-)$ \\
\hline 16) S I & 34 & AUG & Soup Land & $100<$ & 6.25 & $(+)$ & & $(+)$ \\
\hline 17) $\mathrm{H} \mathrm{I}$ & 55 & AUG & Soup Land & 100 & 12.5 & & $(+)$ & $(-)$ \\
\hline 18) $\mathrm{MO}$ & 44 & AUG & Taiwan & $100<$ & 12.5 & & $(+)$ & $(-)$ \\
\hline 19) $\mathrm{TM}$ & 56 & OCT & Call Girl & $100<$ & 3.13 & & $(+)$ & $(-)$ \\
\hline 20) $\mathrm{AT}$ & 38 & DEC & Soup Land & $100<$ & 6.25 & & $(+)$ & $(-)$ \\
\hline 21) $\mathrm{H} \mathrm{S}$ & 42 & DEC & Korea & $100<$ & 12.5 & & $(+)$ & $(-)$ \\
\hline 22) $\mathrm{TK}$ & 34 & DEC & Call Girl & 100 & 6.25 & & $(+)$ & $(-)$ \\
\hline
\end{tabular}

N.T : Not tested, Md : Megadalton

会的，文化的に国際交流が盛んになり，日本人が アフリカを含めた世界各地で活動している昨今, 本邦でアフリカ型PPNG が認められないのは不 可解なことであった。そこで今回,われわれは1988 年に臨床分離された PPNG 22株を検索したが, その結果, 3 株のアフリカ型 PPNG を検出し, 本 邦にアフリカ型 PPNGが持ち込まれていること が証明された。また，これら 3 株の感染源は， 1 例はフィリピンであったが， 2 例は都内のソープ ランドであり，アフリカ型 PPNG が, 既に国内に 定着していることを示すものと思われる.

また，今回検出されたアフリカ型 PPNG 3 株

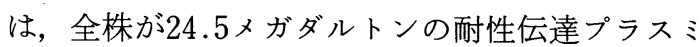
ドを持ついわゆる新アフリカ型 PPNGであっ た.このことからも, 今後, アフリカ型 PPNGが 容易に広がって行くことが推測される。アジア型 PPNG は今回19株検出されたが，そのうち 5 株

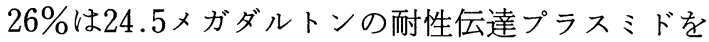

有しており，アジア型 PPNG も本邦で増加する ものと思われた。

PPNG の薬剤耐性について，これまでアジア型 PPNG は TC 耐性, アフリカ型 PPNG は TC 比 較的感受性 ${ }^{110)}$ とされていたが, 今回のアフリカ型 PPNG 3 株はアジア型 PPNG と同様に TC 耐性 であり，従来の報告とは違った成績であった。今 後, 本邦でも数多くのアフリカ型 PPNG が分離 されると思われるが，それらの薬剂耐性パターン の変化が注目される。

本論文の要旨は, 第63回日本感染症学会総会に抒いて報 告した.

\section{文献}

1) Perine, P.L., Trornsberry, C., Schalla, W., et al.: Evidence of two distrinct types of penicllinase-producing Neisseria gonorrhoeae. Lancet, 12 : 993-995, 1977.

2）加納堯子，大久保暢夫：都民より分離したりん菌 の薬剤感受性と PC 耐性リン菌. 東京都衛生局学 
会誌, 66:54-55, 1981.

3) Yosida, S., Ohta, H., Taniguchi, H., et al. : Plasmid profiles of penicillinase-producing Neisseria gonorrhoeae isolated in Fukuoka, Japan. Microbiol. Immunol., 28 : 955-959, 1984.

4）池田文昭，金子康子，西田 実，他：PPNG（ぺ ニシリナーゼ産生淋菌) の耐性と疫学. 臨床と細 菌（臨時増刊, STD一病因・診断・治療一), p. 45 $-53,1984$.

5）酒井 茂, 熊本悦明, 西村昌政: 淋菌感染症一細 菌学的検討一. STD 現状と問題点. p. 21-34, ラ イフ・サイェンス, 東京, 1987.

6) Phillips, I. : $\beta$-lactamase-producing Penicillin-resistant gonococcus. Lancet, $25: 656$ $-657,1976$.

7) Ashford, W.A., Golash, R.G. \& Hemming, V.C. :
Penicillinase Producing Neisseria gonorrhoeae. Lancet, 25 : 657-658, 1976.

8）小野田洋一, 三井一子, 小原 寧, 他：国内での $\beta$-lactamase 産生淋菌 (PPNG) 検出について. Chemotherapy, $27: 265-268,1979$.

9) Enbden, J.D.A., Klingeren, B., Dessens-Kroon, M., et al.: Emergence in the Nethrlands of penicillinase-producing gonococci carrying 0Africa" plasmid in combination with transfer plasmid. Lancet, 1 : 938, 1981.

10) Osoba, A.O., Johnston, N.A., Ogunbanjo, B.O., et al.: Plasmid profile of Neisseria gonorr hoeae in Nigeria and efficacy of spectinomycin in treating gonorrhoea. Genitourin Med., 63:1 $-5,1987$.

\title{
Detection of African Type PPNG in Japan
}

\author{
Takejiro OKAZAKI \\ Department of Urology, Tokyo Metropolitan Taito Hospital \\ Makoto OHHASHI, Hiroshio HITOKOTO \& Takeshi ISHIGAMI \\ Tokyo Metropolitan Public Health Laboratory \\ Toyohei MACHIDA \& Shoichi ONODERA \\ Department of Urology, The Jikei University School of Medicine
}

The Plasmid DNA patterns of 22 penicillinase-producing Neisseria gonorrhoeae (PPNG) strains isolated from male patients with genococcal urethritis in 1988 at Tokyo Metropolitan Taito Hospital were determined.

The 3.3 megadalton plasmid, the so called the Africantype plasmid, was present in 3 isolates out of 22 PPNGs, all of which occurred with a conjugative 24.5 megadalton plasmid. 4.4 megadalton plasmid was present in 19 isolates out of 22 PPNGs, 5 of which occurred with a conjugative 24.5 megadalton plasmid.

The infective sources of the 3 cases of the African type PPNGs were found as 1 from philippines and 2 from prostitutes, so called Soap Land Girl in Japan. And they suggests that the African type PPNGs are already common in Japan. 